\title{
International Master in Digital Library Learning: Seize the Opportunity*
}

\author{
Bir Uluslararası Yüksek Lisans Programı Tanıtımı
}

Stanislava GARDAŠEVIĆ**

\begin{abstract}
Öz
Bu calışmada yazar, Erasmus Mundus bursiyeri olarak, bağlı bulunduğu International Master in Digital Library Learning (DILL) programını tanıtmaktadır.
\end{abstract}

Anahtar sözcükler: Bilgi ve Belge Yönetimi eğitimi, Yüksek lisans öğrencileri, Uluslararası ögrrenim

\section{Abstract}

In this paper the author presents her own experience as an Erasmus Mundus scholarship holder, which enabled her to undertake the International Master in Digital Library Learning (DILL).

Keywords: LIS Education, Master students, International learning

Everyone who has tried to obtain a scholarship for continuing their education abroad knows how arduous the process can be. For those who are about to pursuit such an action, I would like to share my story of finding, applying, becoming accepted and attending a Master Program in Library and Information Sciences, which will hopefully be able to help you in this process.

As my studies at the University of Belgrade, Faculty of Philology - Department of Library and Information Science were coming to their end, I wanted to continue my education and I intended to do so abroad. As I was already able to speak English quite well, my first impulse was to search for scholarships in the USA, which has a reputation for being a leader in the LIS education. I started to prepare for the application process, which was quite demanding, and at one point I began having second thoughts about my venture.

In the meantime, a friend of mine brought a scholarship program in Europe to my attention, which immediately captured my thoughts. This program in question is called Erasmus Mundus and is offered and financed by the European Commission under the auspices of the Education, Audiovisual and Culture Executive Agency (EACEA).

* This paper published in INFOtheca, 11(2), December 2010.

** Master Student at DILL Program (stanislavabeograd@gmail.com) 
This program had developed more than 100 different Master Programs and 13 Joint Doctorates, and aspires to enhance quality in higher education through scholarships and academic cooperation between Europe and the rest of the world*. Fortunately, among these numerous Master Programs, I found one which perfectly fitted both my interests and educational background, and which is named International Master in Digital Library Learning (DILL).

DILL is a two-year Master Program and is organized in cooperation with Oslo University College (Norway), Tallinn University (Estonia), and Parma University (Italy). The curriculum is organized in such way that students spend at least one semester in each partner institution, under the obligation of passing 2 modules per semester (15 ECTS each). Depending on the subject of a student's master thesis (30 ETCS) and the location of the student's main supervisor, the last semester is spent at one of these tree institutions.

I thoroughly prepared my application for the Master Program and sent it with great expectations. The following prerequisites were required for my applying: a bachelor's degree in an LIS field or other relevant field (180 ETC), sufficient capability in computer usage for information needs and sufficient knowledge of English (verified by scores on TOEFL/IELTS)**. Additionally, every student was required to send his/her own statement of purpose, two letters of reference and any other documents that the administrator asked for in the application process.

As stated on the Master Program's website, these applications are reviewed according to a combination of different factors:

$\diamond \quad$ The relevance and excellence of one's academic background (40\%)

$\diamond \quad$ One's submitted statement of purpose (30\%)

$\diamond \quad$ Any relevant experience and professional training one may have (20\%)

$\diamond \quad$ One's letters of reference $(10 \%)^{* * *}$.

I applied to this program during the first Erasmus Mundus phase. However, the second phase of Erasmus Mundus II started last year with a new budget scheme for the next four years; therein, some of the circumstances for admission have changed.

After applying and being accepted to the program, the DILL consortium applies for a scholarship that Erasmus Mundus offers on behalf of the student. A full scholarship is offered to students from so called 'third world countries', meaning all countries not belonging to EU/ EEA-EFTA states, and it is very generous and covering all the expenses of tuition, living, transportation to and from these countries, health insurance and so on. Beginning from this year, there are 10 scholarships available for students from third world countries, 8 scholarships for students from EU/EEA-EFTA states and 2 scholarships for students from the Western Balkans and Turkey****.

* http://ec.europa.eu/education/external-relation-programmes/doc72_en.htm

** http://dill.hio.no/application/application/

*** http://dill.hio.no/application/admission/

**** http://dill.hio.no/scholarship/ 
This master course also provides a great opportunity for educational and scientific scholars from third world countries who can apply for scholarships to perform scientific research and attend lectures within the DILL consortium for a limited period of time. The scholarship is also available to educational and scientific scholars who hold a PhD in the field of Digital Libraries Sciences and are able to teach in English*.

After finishing my application process, I was naturally eager to hear the results. In the latter part of April, I finally found out that I was accepted and of course I was thrilled by the opportunity given to me. In August I moved to my first semester location which was in Norway in Oslo. When I first arrived there, I encountered the unbelievable experience of it being daylight at $11 \mathrm{pm}$. My new classmates, who were a refreshingly diverse group of people, were made up of people from all over the world; my class (the third generation of DILL students) had 20 students, who came from Uganda, Ethiopia, Iran, India, Pakistan Bangladesh, Vietnam, the Philippines, China, Taiwan, Italy, Indonesia and luckily for my social life, and not so much for perfecting my spoken English, from Bosnia and Herzegovina. There was diversity not only their ethnicity but also in their professional and educational background, due to the fact that the Selection Committee purposefully chose not only students with a background in LIS but also those with IT, business, legal and other educational backgrounds, as to create a mutual exchange of experience among students. Another interesting fact is that the youngest student was 23 years old and the oldest was 55 , which proves there is absolutely no age limit when applying.

The first semester courses were held at Oslo University College, at the Faculty of Journalism and Library and Information Sciences, which was a very pleasant and student-centered place. We completed 2 modules at this institution. The first one was Research Methods and Theory of Science which was intended to introduce us with the research process, and focused on both qualitative and quantitative methods, providing students with a sufficient background for doing their future research for their Master Thesis. The other module was titled "Digital Documents". This module dealt more with practical and technical issues, and covered topics such as: categories, the architecture and challenges of digital libraries, user behavior in a digital environment, indexing, ontologies, semantic networks, the Simple Knowledge Organization System (SKOS), data integration, thematic mapping, Dublin core, information architecture and metadata interoperability.

All my classmates, including me, successfully finished the first semester and after a winter brake we all moved to our next location for the second semester, which was in Tallinn, the capital of Estonia.

Tallinn embraced us with its wonderful mediaeval town and its incredible one and a half meters of snow that persistently continued until the end of March. The faculty

\footnotetext{
* http://dill.hio.no/visiting-scholars/
} 
of the Institute of Information Studies at Tallinn University, where we had another 2 modules, awaited us with a warm welcome. The first module was Human Resource Management, covering theories, practices, tools and models of HRM. The second module was Information and Knowledge Management and was designed for students to acquire knowledge and skills to help them understand values, actual practices, research, and the nature of information and knowledge management. Both of these modules were organized as collaborative problem-based group projects through the entire semester. The lectures were full of discussion and reflection on topics covered by these modules. In addition to the valuable knowledge we gained from the curriculum, I can say that we were able to master another important skill: teamwork.

During our second semester, our class was fortunate enough to hear lectures - both live and by video-conference - from many world famous professors, such as: Christian Schlögl (University of Graz, Austria), Annemaree Lloyd (Charles Sturt University, Australia), Lucy A. Tedd (Aberystwyth University, United Kingdom), Gillian Oliver (Victoria University of Wellington, New Zealand), Peter Ingwersen (Royal School of Library and Information Science, Denmark), Ronald E. Day (Indiana University Bloomington, U.S.A.), Tom Wilson (The University of Sheffield, United Kingdom) and others.

We were given the opportunity to attend an international conference titled "Transforming Culture in the Digital Age" which was held in Tartu. This unique experience allowed us to view the current trends, practices and research methods of many cultural heritage institutions, museums, archives, libraries, and artists who use digital technologies.

Upon completion of our second semester and summer break, our whole group moved to Italy. After a year spent at the very north of Europe, we were all sincerely looking forward to the mild Mediterranean climate and new challenges that Italy and our third semester would bring us.

The third semester started with a two-week summer school in Florence, after which we were ready to start with our modules at Parma University. One of the two modules was Access to Digital Libraries. This module focused on the basic concepts of digital libraries, information access, information discovery, user interfaces and other additional topics related to this subject. The other module was Users and Usage of Digital Libraries: A Quantitative and Qualitative Evaluation. This module was designed to help students to examine how digital libraries are valued by their users, and explore ways of allowing for the allocation of resources to areas of user-identified needs through evaluation and applying research methodologies. Students have to spend the last month of this semester as interns at an institution in Europe that offers Digital Library services, gaining technical and practical skills there which are needed for their future career.

This leads us to our fourth and the final semester, which every student has to spend writing her/his Master's Thesis at one of the three partner institutions. 
The experience of being a DILL student was life altering. I have established wonderful friendships with people from all over the world, was introduced to many interesting cultures, learned to live and cope with these cultural differences, learned a little bit of Norwegian, Russian and Italian, savored homemade African bred and Indian curry and had many other wonderful experiences and memories.

I had the opportunity to travel through many European countries, where I looked into their libraries to catch a glimpse of the environment that unfolds in them, which I hope I will eventually be able to implement in my own country, along with the knowledge I gained from this Master Program.

My advice for those planning to apply for this or any other Master Program abroad is to volunteer and work in the field as much as possible as all such experience will be highly regarded by the Selection Committee; additionally, maintain a high Grade Point Average (GPA) together with your expectations to seize such an opportunity in the future.

\section{References}

http://dill.hio.no/application/admission/ (Retrieved July 25, 2010)

http://dill.hio.no/application/application/ (Retrieved July 25, 2010)

http://dill.hio.no/scholarship/ (Retrieved July 25, 2010)

http://dill.hio.no/visiting-scholars/ (Retrieved July 25, 2010)

http://ec.europa.eu/education/external-relation-programmes/doc72_en.htm (Retrieved July 25, 2010) 